THE INTERNATIONAL

REVIEW OF RESEARCH IN

OPEN AND DISTANCE LEARNING

\title{
Book Review - Learning Theory and Online Technologies
}

Author: Harasim, L. (2012)

New York: Routledge. 208 pages.

ISBN: 978-0-415-9976-2

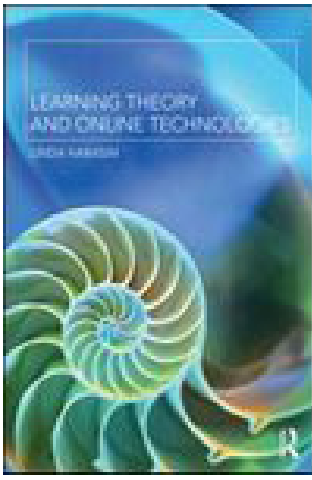

Reviewer: Diane Carver, Old Dominion University, USA

Learning Theory and Online Technologies presents readers with an outline of the current position of online learning, beginning with an historical review of e-learning and learning theories, and proposes a model of e-learning solutions for today's learners. Written by Linda Harasim, professor at Simon Fraser University in Burnaby, British Columbia, the book includes examples of how the online collaborative learning theory can be applied in an online course and provides case studies of how the theory is being implemented in educational institutions.

Harasim begins with an overview of established learning theories and how those various theories relate to technology. Harasim discusses the premise that learning theories reflect the social needs and standards of the time period in which they are developed or gain popularity. Teachers and curriculum designers need to go beyond simply applying the same learning theories and instructional techniques to current technologies and instead must use a new theory to revolutionize education in the $21^{\text {st }}$ century.

Chapters 2 through 5 take the reader on a journey back in time to explore historical learning theories. By applying scientific methods and theories to the study of learning, behaviorism challenged the idea that knowledge was metaphysical. Cognitivism brought to light what could not be seen: the inner workings of the mind. Constructivism held that learning was shaped by individuals based on experience, thoughts, and interactions. In each successive chapter, the author discusses these theories and how they emerged from the economic and workforce needs of the era.

In chapters 2-5 Harasim explains how these learning theories relate to the computer age 
and points out that each theory is insufficient to capture the essence of the collaborative learning of today. According to Chiong and Jovanovic (2012), earlier learning theories, particularly social constructivism, provide evidence of the benefits of collaborative learning. Harasim summarizes the connections between the high-technology collaboration today and previous learning theories and takes it one step further to develop a new theory for the knowledge age. She refers to this new theory as online collaborative learning.

In the most compelling chapter, chapter 6, the author discusses the "Net Generation" from their birth into an online environment to the sheer size of their population, which stands at over two billion individuals. As this generation of learners and employees search for the most efficient way to solve problems and extend their mental capabilities, collaborative learning in the knowledge age is a natural progression. The author stresses the importance of exploration and development of this new learning theory to reflect the unique opportunities and challenges facing education in an online environment. She then describes the online collaborative learning theory for the information age.

Harasim suggests that much like earlier learning theories, online collaborative learning builds upon prior theories while expanding into new directions in response to new societal and educational needs. In particular, invention and adoption of the Internet presented a paradigm shift and created profound consequences for teaching and learning. The creation of knowledge, not just the transmission of knowledge, has become the primary method for learning in today's collaborative online environment. This construction of knowledge based on shared experiences and interests is similar to the constructivist theory, but the online collaborative learning theory emphasizes cooperation which is not highlighted in the constructivist model.

Harasim believes that online collaborative learning will enhance or contribute to learning activities by "providing a theoretical framework to help design and inform. .." (p. 92) online instructional practices. The online collaborative learning process involves cooperative learning and construction of knowledge through convergent and divergent thinking, much like group brainstorming. Collection of numerous questions and ideas leads to alternative responses and solutions. These are then filtered and condensed through online collaborative efforts. As one may guess, the need for sophisticated learning technology goes handin-hand with development of this theory, and Harasim devotes the end of chapter 6 to a discussion of interactive learning technologies and online content.

Chapter 7 outlines fictional and semifictional scenarios describing online learning through text-based activities, case studies, simulations, student-led presentations, and games. Chapter 8 follows actual case studies through online secondary and postsecondary educational programs that have implemented online collaborative learning methods. In this chapter, Harasim discusses the history, student support structure, faculty training, and learning approaches of several online institutions including those of the University of Phoenix and The Virtual High School.

In chapter 9 Harasim provides examples and discussion pertaining to online communities 
of practice which are defined as "groups of people informally bound together by shared expertise and passion for a joint enterprise. ..” (Wenger \& Snyder, 2000, p. 139). Examples of communities of practice include the Global Educators Network and Wikipedia. Finally, chapter 10 provides a summary and thoughts for the future.

This book should be required reading for all teachers, not only those who teach online. Many educators tend to work within the parameters of earlier learning theories; changing that paradigm for the knowledge age presents a major shift. The commonality of the previous learning theorists is in their propensity toward individualistic and didactic methods for imparting knowledge from teacher to student. This relatively passive learning process is not consistent with today's collaborative working and learning environments. Harasim's online collaborative learning theory contends that knowledge and learning should be shared not only between teacher and student, but also among groups of learners. Harasim ends her book by reminding us that "teachers and learners today have the fortunate opportunity to contribute to and participate in shaping this new online environment, and thereby, most importantly, fully engage in their mission of advancing the conversation of humankind" (p. 174).

\section{References}

Chiong, R., Jovanovic, J., \& Gill, T. G. (2012). Collaborative learning in online study groups: An evolutionary game theory perspective. Journal of Information Technology Education, 11, 81-101.

Harasim, L. (2012). Learning theory and online technologies. Marceline, MO: Walsworth Publishing Company.

Wenger, E.C., \& Snyder, W.M. (2000). Communities of practice: The organizational frontier. Harvard Business Review, 78(1), 139-145.

\section{Athabasca University $\mathbf{1}$}

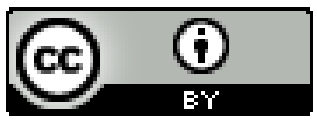

